\section{KITEKINTÉS A MAGÁN-EGÉSZSÉGBIZTOSÍTÁSOK LEGELTERJEDTEBB SZABÁLYOZÁSI MEGOLDÁSAIRA}

Tőkey Balázs (adjunktus, ELTE ÁJK, Polgári Jogi Tanszék) tokeybalazs@ajk.elte.hu

\section{ÖSSZEFOGLALÓ}

Cikkünk az önkéntes egészségbiztosításokhoz kapcsolódó legfontosabb szabályozási kérdéseket vizsgálja külföldi megoldások bemutatásának segítségével.

Ezek a rendelkezések több, egymásnak ellentmondó célt szolgálnak. Először is, minél több embernek legyen lehetősége arra, hogy egészségbiztosítást kössön (például kötelező befogadás és élethosszig tartó fedezet alkalmazásával). Ezek a biztosítások nyújtsanak minél szélesebb egészségbiztosítási fedezetet (például minimális szolgáltatási csomag előírásával vagy a várakozási idő alkalmazásának korlátozásával). És természetesen a biztosítások dija senki számára se legyen megfizethetetlenül magas (például közös díjszabás elöírásával vagy a biztosítási szerződés módosításának korlátozásával).

\section{SUMMARY}

In our article we go over the most important questions about the regulation of voluntary health insurances with the help of interpretation of the solutions applied worldwide.

However, the aims of these rules are controversial. The first one is to make these health insurances available for as many people as possible (e.g. by open enrolment and life time cover). At the same time the coverage of these insurances should be as wide as possible (e.g. with the help of prescription of minimal benefits or restriction of application of waiting periods). And finally, the premiums must not be so high that someone could not afford to have a health insurance (e.g. by community rating or restriction of modification of the insurance contracts).

Kulcsszavak: kötelező befogadás, közös díjszabás, élethosszig tartó fedezet, kockázatkiegyenlítő rendszer, várakozási idő

JEL: I13, I18

Key words: open enrolment, community rating, lifetime cover, risk equisalation mechanism, waiting period

JEL: I13, I18

DOI: $10.18530 /$ BK.2015.4.48

http://dx.doi.org/1018530/BK.2015.4.48

\section{Bevezetés}

A magán-egészségbiztosítások szabályozásának elemzését meglehetősen megnehezíti az a tény, hogy az egyes egészségbiztosítások egymástól igencsak eltérőek lehetnek, az egyes biztosítások funkciója, az egészségügyi rendszerben betöltött szerepe és elterjedtsége nagyon változatos képet mutat. Így egy magán-egészségbiztosítás lehet akár összeg-, akár kárbiztosítás. Kárbiztosítás esetén a biztosító szolgáltatása a biztosítottat ért vagyoni kár megtérítése (például a biztosítás valamely egészségügyi ellátáshoz kapcsolódó szolgáltatás költségét fedezi, vagy a betegség miatt kiesett keresetveszteséget kompenzálja), összegbiztosításnál viszont a biztosítónak a biztosítási esemény bekövetkeztekor az elöre meghatározott összeget kell megfizetnie, függetlenül attól, hogy a biztosítási eseménynek milyen hatása van a biztosított vagyoni helyzetére (például a biztosító minden kórházban vagy betegállományban töltött nap után előre meghatározott összegű napidíjat fizet).

A kárbiztosításként megkötött, az egészség helyreállítására és megőrzésére szolgáló egészségbiztosítások között elkülöníthetőek a szolgáltatásfinanszírozó és az utólagos költségtérítést nyújtó egészségbiztosítások. Az előbbi esetén a biztosító arra vállal kötelezettséget, hogy a biztosított által igénybe vett egészségügyi szolgáltatások költségét utólag pénzben megtéríti; ezek a jellemzők például Németországban (Langheid-Wandt, 2009-2010). Az utóbbi esetén viszont a biztosító elsősorban nem pénzben való megtérítést vállal, hanem magának az orvosi ellátásnak az igénybevételét teszi lehetővé a biztosított számára, a szolgáltatását természetben nyújtja a vele szerződött egészségügyi szolgáltatókon keresztül; ezek a jellemzők például Spanyolországban (García-Armesto-Abadía-Taira-Durán at al., 2010).

Ehhez hasonló módon egymástól igen eltérő sajátosságokkal rendelkeznek a kötelező és az önkéntes egészségbiztosítások. Kötelező magán-egészségbiztosításról olyan esetekben beszélhetünk, amikor jogszabály kötelezővé teszi az egészségbiztosításban való részvételt, és a lakosságnak legalább egy része ezt a kötelező egészségbiztosítási védelmet magán-egészségbiztosítás megkötésével teremti meg. A kötelező magán-egészségbiztosításoknak két altípusa ismert. Az egyik esetben jogszabályi elöírás következtében a lakosság egésze rendelkezik magánbiztosítással, amely a magánbiztosítások által fedezett kockázatok körében az állami egészségbiztosítást ki is váltja, helyettesíti. Ilyen kötelező magán-egészségbiztosítási rendszert találhatunk például Hollandiában (HIN) és Svájcban (Daley-Gubb). A kötelező magán-egészségbiztosítás másik modelljének a német megoldás tekinthető: jogszabály csak a lakosság egy - jelentős - része számára írja elő kötelezően az állami egészségbiztosításban való részvételt. Akiket nem érint ez a kötelezettség, azok vagy egyéb okból jogosultak egészségügyi szolgáltatások igénybevételére (például köztisztviselőként az állam fedezi az egészségügyi ellátásaik költségét), vagy választhatnak, hogy milyen módon teremtik meg a maguk számára az egyébként kötelező egészségbiztosítási fedezetet: például ők is csatlakoznak az állami egészségbiztosításhoz, vagy magán-egészségbiztosítást kötnek (Langheid-Wandt, 2009-2010). 
A kötelező magán-egészségbiztosításoknál sokkal elterjedtebbek az önkéntes magán-egészségbiztosítások, a legtöbb országban csak ez utóbbi forma található meg, ez azonban lényegében a világ valamennyi fejlett országában fellelhetö. Az önkéntes és a kötelező egészségbiztosítások nem zárják ki egymást: azokban az országokban, ahol bevezették a kötelező magán-egészségbiztosítás valamelyik modelljét, szintén megtalálhatóak az önkéntes magán-egészségbiztosítások a kötelező egészségbiztosítás által nem fedezett szolgáltatások biztosítására.

Végül az is erősen meghatározza egy egészségbiztosítás jellegét, hogy hogyan kapcsolódik az állami egészségügyi rendszerhez, így megkülönböztethetőek a helyettesítő, a párhuzamos és a kiegészítő egészségbiztosítások (PMIEU, 2011). A helyettesítő egészségbiztosítás az állami egészségügyi ellátások kiváltására szolgál. Ilyen biztosítások például Németországban érhetők el (Langheid-Wandt, 2009-2010), ahol a lakosság egy része nem köteles részt venni az állami egészségbiztosításban, és ők az egészségbiztosítási fedezetüket magán-egészségbiztosítással is megteremthetik. Tulajdonképpen a kötelező magán-egészségbiztosításokat (például Hollandia és Svájc) is helyettesítő egészségbiztosításoknak tekinthetjük, hiszen ilyenkor az egészségügy finanszírozása a magán-egészségbiztosítási rendszer feladata, és ezzel helyettesítik az állami egészségügyet.

\section{Megküilönböztethetőek a helyettesítő, a párhuzamos \\ és a kiegészítő egészségbiztosítások.}

Párhuzamos biztosítások keretében - szemben a helyettesítő biztosításokkal - az ügyfél olyan szolgáltatásokat vehet igénybe, amelyekre egyébként az állami egészségügy keretében is jogosult lenne. Ezek a biztosítások olyan országokra jellemzőek, ahol az állami egészségügyi ellátás lényegében minden lakosnak jár, azok egy része azonban magasabb színvonalú vagy gyorsabban hozzáférhető egészségügyi szolgáltatásokat szeretne. Îgy az ügyfél tulajdonképpen duplán fizet az egészségügyi szolgáltatásokért. Ezek a biztosítások jellemzőek például Írországra vagy Ausztráliára (Thomson-Mossialos, 2009). A helyettesítő és párhuzamos biztosításoknál sokkal elterjedtebbek a kiegészítő biztosítások, amelyek önmagukban nem alkalmasak az egészségi kockázatok fedezésére, mindössze az állami egészségügyi ellátásban elérhető szolgáltatásokat egészítik ki. E kiegészítő biztosítások két csoportra oszthatók: vagy az állami egészségügyben való részvétel során nyújtanak magasabb színvonalú szolgáltatást (például egyágyas kórházi elhelyezést), esetleg fedezetet az állami egészségügy szolgáltatásai után fizetendő önrészre, vagy olyan egészségügyi, illetve ahhoz kapcsolódó szolgáltatásokat fedeznek, amelyekre az állami biztosítás egyáltalán nem terjed ki (például fogászati ellátás vagy alternatív gyógymódok fedezése). Az önrészt fedező egészségbiztosítások értelemszerűen azokban az országokban találhatóak meg, ahol az állami egészségügy igénybevétele esetén a költségek egy része magukat a betegeket terheli. Ezek a biztosítások például Franciaországra, Belgiumra és Szlovéniára jellemzőek (Thomson-Mossialos, 2009).
A továbbiakban vizsgálódásunkat elsősorban azokra a kulcskérdésekre fogjuk szükíteni, amelyek egészségügyi ellátáshoz kapcsolódó szolgáltatások költségét fedező (azaz kárbiztosításnak minősülő) kiegészítő egészségbiztosítások szabályozásával kapcsolatosan merülnek fel, mert hazánkban leginkább ezek esnek a szakmai érdeklődés középpontjába. Elemzésünk során igyekszünk röviden bemutatni az egyes problémakörökhöz kapcsolódó sajátos megoldások okait, esetleges előnyeit és hátrányait is.

\section{1. Ügyfelek befogadása}

A magán-egészségbiztosítási szerződés szabályozása kapcsán az az egyik legfontosabb kérdés, hogy a biztosító köteles-e minden ügyféllel szerződést kötni. Kötelező befogadásnak (open enrolment) hívjuk azt a szabályozást, amikor jogszabály írja elő a biztosító számára, hogy valamennyi ügyféllel köteles biztosítást kötni, függetlenül attól, hogy milyen egészségbiztosítási kockázatokkal rendelkezik (különös tekintettel az életkorára és a már fennálló betegségeire).

Értelemszerűen kötelező magán-egészségbiztosítás esetén (mint például Svájcban vagy Hollandiában) a biztosítók valamennyi jelentkező ügyféllel kötelesek szerződést kötni. Ennek hiányában ugyanis a magas kockázatú ügyfeleket egyik biztosító sem fogadná be, és így nem tudnának eleget tenni annak a jogszabály által előírt kötelezettségüknek, hogy rendelkezzenek egészségbiztosítással.

\section{Az egyik legfontosabb kérdés, hogy a biztosító \\ köteles-e minden ügyféllel szerződést kötni.}

Az Affordable Care Act (ACA) vonatkozó szabályának hatálybalépése után ma már lényegében az Amerikai Egyesült Államokban is kötelező magán-egészségbiztosításról beszélhetünk, hiszen azok, akik nem rendelkeznek minimális egészségbiztosítási fedezettel, 2014 januárjától magasabb adófizetési kötelezettséggel számolhatnak, kivéve például, ha nem rendelkeznek a meghatározott minimális jövedelemmel, vagy a biztosítás egy före jutó költsége meghaladná a háztartás bevételének 8 százalékát. Ennek megfelelően itt is a kötelező befogadás szabálya érvényesül, mert a biztosítók egyáltalán nem utasíthatnak el ügyfeleket a fennálló egészségügyi állapotuk vagy életkoruk miatt. A szabályozás annyiban sajátos, hogy előre meghatározzák az évnek azt a szakaszát, amikor az egyéni biztosítottak biztosítást köthetnek (vagy biztosítást válthatnak). Így a legutóbbi ún. „open enrollment period” 2014. november 15-étől 2015. február 15-éig tartott. A jövőben várhatóan az adott év október elsejétől december 15-éig lehet majd a biztosítóknál jelentkezni (Obamacare).

Németországban a kötelező befogadás a bázistarifák vonatkozásában érvényesül, amelyek szolgáltatása megegyezik az állami egészségbiztosítás által nyújtott fedezettel. Minden biztosító köteles bázistarifán alapuló biztosítási terméket kínálni valamennyi jelentkező ügyfél számára (Langheid-Wandt, 2009-2010). 
Az önkéntes egészségbiztosítások tekintetében viszont a legtöbb országra az a jellemző, hogy a biztosítók szabadon dönthetik el, hogy melyik ügyféllel kívánnak szerződést kötni. Emellett azonban arra is találhatunk példát, hogy a jogalkotó önkéntes egészségbiztosítások esetén is elöírja a kötelező befogadás valamely formáját. Erre példaként Belgiumot, Írországot, Szlovéniát, Ausztráliát vagy a Dél-afrikai Köztársaságot említhetjük.

Belgiumban a vonatkozó jogszabály mondja ki, hogy nem utasíthatók el a 65 év alatti ügyfelek valamilyen meglévő betegségük miatt (tehát a 65 év felettiekre nem vonatkozik a kötelező befogadás), de az egészségbiztosítási pénztárak (amelyeknek alapvetően a társadalombiztosítás finanszírozása a feladata, de emellett nyújthatnak magán-egészségbiztosítási szolgáltatásokat is) összegszerűen korlátozhatják az ilyen ügyfeleknek nyújtandó szolgáltatásokat, a profitorientált biztosítók pedig kizárhatják a már meglévő betegségek miatt szükségessé váló szolgáltatásokat (Gerken-Merkur)

Írországban és Ausztráliában a biztosítóknak választaniuk kell, hogy vagy csak nyílt, vagy csak korlátozott hozzáférésű biztosításokat (adott munkavállalókra vagy szakmát végzőkre szabott csoportos biztosításokat) kínálnak. Ausztráliában csak a nyílt hozzáférésü biztosításokat nyújtó biztosítóknak kell valamennyi jelentkező ügyfelet befogadniuk, tehát a kötelező befogadás szabálya csak rájuk vonatkozik teljes egészében. A korlátozott hozzáférésű biztosítások tekintetében ugyanis csak korlátozottan érvényesül a kötelező befogadás: a biztosítónak csak az adott csoportba tartozókkal (például egy adott cég munkavállalóival és az ő hozzátartozóikkal) kell biztosítást kötnie (PHIO). Ezzel szemben Írországban valamennyi, tehát a nyílt és korlátozott hozzáférésű biztosításokra is teljes mértékben érvényesül a kötelező befogadás szabálya. Azaz a korlátozott hozzáférésű biztosítások (restricted membership insurance) csak a nevükben azok, mivel a biztosítók olyan személyekkel is kötelesek megkötni ezeket a biztosításokat, akik nem tartoznak abba a csoportba, amelyre célzottan a feltételeket a biztosító kialakította (HIE). A Dél-afrikai Köztársaságban a biztosítók mind nyílt, mind korlátozott hozzáférésű biztosításokat is nyújthatnak, és ez utóbbiakba csak az adott csoportba tartozók jogosultak jelentkezni (CMS).

Szlovéniában pedig csak azokra a kiegészítő biztosításokra vonatkozik a kötelező befogadás, amelyek az állami egészségügy igénybevétele során a betegek által megtérítendő költségeket fedezik (Thomson-Mossialos, 2009).

A fenti példákat nézve az állapítható meg, hogy a jogszabály akkor írja elő a kötelező befogadás szabályát önkéntes kiegészítő biztosítások (vagy azok egy része) vonatkozásában, ha az adott ország egészségügyi rendszeréből következően a jogalkotó azt kívánja elérni, hogy a lakosság nagy része rendelkezzen ilyen típusú egészségbiztosítással, mert például az állami egészségügy nem ingyenesen hozzáférhető a teljes lakosság számára. Így Belgiumban és Szlovéniában e biztosítások alapvetően a betegek által igénybe vett egészségügyi szolgáltatások önrészét fedezik, Írországban pedig a lakosság kétharmadának fizetnie kell az állami egészségügyi szolgáltatásokért. Nem véletlen, hogy ezekben az országokban a lakosság többsége rendelkezik is kiegészítő egészségbiztosítással (Thomson-Mossialos, 2009).
Végül megjegyezzük, hogy az ügyfelek befogadásához kapcsolódó szabályozási kérdés az is, hogy a biztosító köteles-e az ügyfél hozzátartozóját is biztosítani. Értelemszerűen ez akkor releváns kérdés, ha az adott biztosításra nem vonatkozik a kötelező befogadás. Ilyen jogszabályi előírás nem jellemző, de találhatunk rá példát: Németországban a biztosítási szerződési törvény (Versicherungsvertragsgesetz, VVG) VVG 198. \$-a valamennyi belföldi hatályú egészségbiztosítás vonatkozásában úgy rendelkezik, hogy ha ezt igénylik, akkor a biztosító köteles kiterjeszteni a biztosítási védelmet a biztosított újszülött és örökbe fogadott gyermekére is, ráadásul újszülött esetén még kockázati pótlékot sem számíthat fel. A biztosító feltételként csak a biztosított szülő biztosításának korábbi fennállására vonatkozóan írhat elő minimális időtartamot, de ez sem lehet több három hónapnál.

\section{Díjszabás}

A magán-egészségbiztosítások szabályozásának másik kulcskérdése az ügyfelek befogadása mellett a díjszabás meghatározása. Ennek keretében az a leglényegesebb pont, hogy a biztosítók a biztosítási díjaik kalkulálása során milyen kockázati tényezőket vehetnek figyelembe.

A legradikálisabb megoldás a közös díjszabás (community rating), amely azt jelenti, hogy a biztosítók valamennyi ügyfelüknek azonos díj ellenében kötelesek biztosítást nyújtani. A közös díjszabás a jellemző a kötelező magán-egészségbiztosításokra (például Hollandia és Svájc), valamint a helyettesítő biztosításokra (lásd a bázistarifák vonatkozásában Németországot). Emellett azonban a közös díjszabást néhány országban - ha korlátozásokkal is - a kiegészítő biztosításokra is alkalmazzák (például Îrországban, Ausztráliában, a Dél-afrikai Köztársaságban vagy Szlovéniában, utóbbi esetén kifejezetten csak az állami egészségügy igénybevétele során a betegek által megtérítendő költségeket fedező biztosításokra).

Ennek megfelelően a példaként említett Îrországban a biztosítók életkortól, nemi hovatartozástól, egészségi állapottól stb. függetlenül azonos áron kötelesek az egészségbiztosítási termékeiket kínálni valamennyi ügyfél számára. E föszabály alól azonban van néhány kivétel. Egyrészt a 18 évesnél fiatalabbak, a 18 és 23 éves kor közötti továbbtanulók, valamint meghatározott esetben a korábbi munkáltatójuk által kötött egészségbiztosítás alapján jogosult nyugdíjasok biztosítási díjai alacsonyabbak lehetnek, és csoportos biztosítás esetén legfeljebb 10 százalékos díjkedvezmény adható. Másrészt 2015. május 1-jétől azok a személyek, akik legalább 35 évesen kötik meg az első egészségbiztosításukat, pótdíjat kötelesek fizetni. A pótdíj nagysága az általános díj 2 százaléka minden egyes olyan életév után, amennyivel a biztosított belépési életkora meghaladja a 34 éves életkort. Tehát egy 35 éves korban belépő biztosított 2 százalékos, egy 50 éves életkorban belépő biztosított pedig 32 százalékos pótdijat fizet egészen addig, amíg egészségbiztosítással rendelkezik. A pótdíj maximuma 70 százalék, tehát azok, akik 69 évesen vagy annál idősebben kötnek először egészségbiztosítást, 70 százalékos pótdíjat kötelesek fizetni. Ennek az új szabályozásnak a hátterében a közös díjszabás fenntarthatóságának biztosítása áll. Ugyanis abban az esetben, ha nem kötelező a magán-egészségbiztosítás megkötése, de a biztosítók egységes dijakat kötelesek alkalmazni, 
akkor fennáll annak a veszélye, hogy egyre többen csak idősebb korban kötnek biztosítást, amikor már jelentőssé válik az egészségbiztosítási kockázatuk. Ha viszont csökken a fiatal és kevésbé kockázatos személyek száma a kockázatközösségben, azzal az egész közösség kockázata megnő, ami még magasabb biztosítási díjakat eredményez. Ez a jelenség a fenti pótdíjjal visszaszorítható, mert így a biztosítottak érdekeltté válnak a minél fiatalabb kori belépésre (HIA). Egyébként ehhez hasonló pótdíjazási rendszer működik a Dél-afrikai Köztársaságban és Ausztráliában, az utóbbiban többek között azokkal az eltérésekkel, hogy már 30 éves belépési kor felett kell pótdijat fizetni, viszont tízéves fizetés után megszűnik a pótdífizetési kötelezettség, amely egyébként csak az 1934. július 1-je után születettekre vonatkozik (PHIO).

Megjegyezzük, hogy a közös díjszabás jellemzően együtt jár egy kockázatkiegyenlítő rendszer működésével (risk equalisation scheme). Ilyen működik a kötelező egészségbiztosítások vonatkozásában Hollandiában és Svájcban, a bázistarifák tekintetében Németországban, az önkéntes biztosításokra pedig Írországban, Ausztráliában és Szlovéniában (ez utóbbi esetén állami egészségügy igénybevétele során a betegek által megtérítendő költségeket fedező biztosításokra). E rendszerek működtetésére azért van szükség, hogy ne kerüljenek hátrányba azok a biztosítók, amelyek kockázatközösségei magasabb kockázatú személyekből állnak. A kockázatkiegyenlítő mechanizmusoknak az a lényegük, hogy előre meghatározott szabályok szerint a kockázatosabb biztosítottakkal rendelkező biztosítók felé a kevésbé kockázatos állománnyal rendelkező biztosítók bevételeinek egy részét átcsoportosítják. Megjegyezzük, hogy az ír kockázatkiegyenlítő rendszernek az európai versenyjoggal való összeférhetőségét az Európai Unió Elsőfokú Bírósága is vizsgálta a T-289/03. sz. ügyben. Ebben azt mondta ki, hogy a kockázatkiegyenlítés általános gazdasági érdekủ szolgáltatási kötelezettségek ellentételezéseként fogható fel, és ha az ellentételezés számítási alapjául szolgáló szempontok előzetesen megállapítottak, objektívek és átláthatók, annak alkalmazása szükséges és arányos, valamint a mértéke a felmerülő költségekhez igazított, akkor az összeegyeztethető az Európai Unió Működéséről Szóló Szerződés versenyjogi rendelkezéseivel.

\section{A közös díjszabás jellemzően egyuitt jár egy \\ kockázatkiegyenlítő rendszer müködésével.}

A fentiektől eltérően a legtöbb országban nem alkalmazzák a közös díjszabást. Ez azonban nem jelenti azt, hogy a biztosítók teljesen szabadon határozhatnák meg a biztosítási díjaikat. Ezzel kapcsolatos korlátozás leggyakrabban a genetikai adatok és a nemi hovatartozás vonatkozásában fordul elő.

Ma már számos országban jogszabály tiltja azt, hogy a biztosítók az egészségbiztosítási díjaik meghatározásához genetikai adatokat használjanak fel, vagy genetikai vizsgálatok elvégzésére kötelezzék az ügyfeleket. Ilyen tilalmat tartalmaz például az Amerikai Egyesült Államokban a 2008-ban elfogadott genetikai adatokon alapuló hátrányos megkülönböztetést tiltó törvény (Genetic Information Nondiscrimination Act of 2008, GINA), Németország- ban a humángenetikai vizsgálatokról szóló törvény (Gesetz über genetische Untersuchungen bei Menschen, GenDG) 18. \$-a, Franciaországban a közegészségügyi kódex (Code de la santé publique) L-1141-1 paragrafusa vagy Ausztriában a géntechnikai törvény (Gentechnikgesetz, GTG) 67. \$-a. Inkább kivételesnek számít az, hogy a genetikai tulajdonságokat mint kockázati tényezőt figyelembe vegyék, erre példaként Kanada szolgál (CCGF).

A nemi hovatartozás szintén egyre kevesebb országban befolyásolhatja az egészségbiztosítások diját. Ezen a téren a legnagyobb változást az Európai Unió Bíróságának a C-236/09. sz., Test-Achatsügyben 2011. március 1-jei ítélete hozta. Ez a 2004/113/EK irányelv 5. cikkének (2) bekezdését, mely a nők és férfiak közötti hátrányos megkülönböztetés alóli kivételként lehetőséget adott a biztositóknak nemenként eltérő biztositási tarifák alkalmazására, 2012. december 21-i hatállyal érvénytelennek nyilvánította. Ugyan az ítéletet a biztosítási szakma erősen vitatta, ennek ellenére a tagállamok kénytelenek voltak a fenti határidőig a vonatkozó szabályozásukat módosítani, és azóta a biztosítók az Európai Unióban valamennyi biztosítás, így az egészségbiztosítások esetén is csak uniszex tarifákat alkalmazhatnak. Megjegyezzük, hogy az Európai Unióhoz hasonlóan az Amerikai Egyesült Államokban sem vehetik figyelembe az egészségbiztosítók a nemi hovatartozást, mivel 2014 óta csak az alábbi tényezők befolyásolhatják a biztosítási dijat: a biztosított keresete, kora, dohányzása, a család mérete, a földrajzi elhelyezkedés és a nyújtott szolgáltatások (Obamacare).

\section{Szolgáltatási csomagok előírása}

A kötelező biztositások esetén a jogalkotó értelemszerűen előírja azt a minimális egészségbiztosítási fedezetet, amelyet az egészségbiztosításoknak nyújtaniuk kell, hiszen ennek hiányában a biztosításkötési kötelezettség nem lenne értelmezhető. Az önkéntes biztosításoknál azonban jellemzően a biztositók szabadon határozhatják meg azt, hogy egyes biztosítási termékeik milyen szolgáltatásokat foglalnak magukban. Ennek megfelelően kivételesnek mondható az az írországi szabályozás, amely meghatározza a kórházi költségeket is fedező, önkéntes egészségbiztosítások minimális tartalmát. Így Írországban ezeknek a biztosításoknak minimálisan különösen az alábbi ellátásokat kell magukban foglalniuk: fekvőbeteg-ellátás, járóbeteg-ellátás, anyasági és pszichiátriai ellátások (HIA).

Eza megoldás egyrészt értelemszerüen azt szolgálja, hogy a biztosítottak valódi, ne csak névleges fedezetet kapjanak, ugyanis a biztosítóknak azáll érdekükben, hogy minél több szolgáltatást kizárjanak az adott csomagból. Másrészt ezzel összehasonlíthatóvá válnak az ügyfelek számára az egyes biztosítási termékek. Ugyanakkor egyáltalán nem egyszerű meghatározni azt, hogy hol legyen a minimális fedezet határa: minél több szolgáltatást von ebbe a körbe a jogalkotó, annál magasabbak lesznek a biztositási díjak, ami viszont egyre több embert tarthat távol az egészségbiztosításoktól.

\section{Várakozási idő}

A várakozási időnek, amely a biztosítás megkötése során fel nem ismerhető, látens kockázatok kiszűrésére szolgál (Bach-Moser 2009), az egészségbiztosítások körében fokozott 
jelentősége van. Hiszen a kockázatok pontos felmérése más biztosításokhoz képest jelentősen nehezebb. A várakozási idő egyik legfontosabb célja az egészségbiztosítások körében az, hogy kivegye azokat a betegségeket a biztosítási fedezetből, amelyek már a biztosítás megkötésekor fennálltak, de akkor még nem voltak felismerhetőek, ugyanakkor a várakozási idő befejeződése előtt szükségessé válik a kezelésük. Természetesen az is elkerülendő, hogy egyes személyek a biztosító előtt a betegségüket eltitkolva akkor kössenek magán-egészségbiztosítást, amikor már valamilyen egészségügyi ellátásra szorulnak (Beckmann-Matusche-Beckmann, 2009), és esetleg a kezelés igénybevétele után fel is mondják azt. Így a várakozási idő nemcsak a biztosítót, hanem a kockázatközösséget is védi a visszaélésektől.

\section{Kötelező biztosítások esetén a jogallkotó előírja \\ a minimális egészségbiztosítási fedezetet.}

Az egészségbiztosítások körében mind az általános, azaz minden kockázatra vonatkozó várakozási időt, mind a különös, azaz egy adott kockázatra vonatkozó várakozási időt alkalmazni szokták. Emellett olyan megoldás is előfordul, hogy a biztosító az adott kockázatot nem teljesen zárja ki, hanem a várakozási idő alatt bekövetkezett biztosítási esemény alapján csak korlátozott szolgáltatás nyújtását vállalja.

Gyakran előfordul az, hogy kiegészítő egészségbiztositások vonatkozásában is jogszabályban korlátozzák a maximálisan kiköthető várakozási időt. Ennek az az oka, hogy a biztosítók értelemszerűen érdekeltek minél hosszabb várakozási idők kikötésében, éppen ezért a minél szélesebb és gyorsabban hozzáférhető egészségbiztosítási fedezet megteremtése érdekében több országban is szabályozzák ezt a kérdést.

A német és az osztrák szabályozás e téren (is) igen hasonló. A VVG 197. \$-a alapján az általános várakozási idő a három hónapot, a szülésre, pszichoterápiára, fogorvosi kezelésre, fogpótlásra és szájsebészetre vonatkozó különös várakozási idő pedig a nyolc hónapot nem lépheti túl. Az osztrák biztosítási szerződési törvény (Versicherungsvertragsgesetz, VersVG) 178d. \$-a annyiban tér el a VVG szabályától, hogy szülésre és az azzal összefüggő kezelésekre vonatkozó különös várakozási idő a kilenc hónapot nem lépheti túl, valamint abban az esetben, ha a biztosítási védelem kifejezetten kiterjed olyan betegségekre vagy baleseti következményekre, amelyek mindkét fél előtt már a szerződéskötés idején ismertek, akkor bármilyen hosszú várakozási idő kiköthető.

Írországban 2015 május 1-jével változott meg a várakozási időre vonatkozó szabályozás. Korábban ugyanis a biztosított életkorától függött a várakozási idő maximálisan megengedett hossza: 55 éves korig 26 hét (már meglévő egészségi állapot vonatkozásában 5 év), 55 és 64 éves kor között 52 hét (már meglévő egészségi állapot vonatkozásában 7 év), 65 éves kor felett pedig 102 hét (már meglévő egészségi állapot vonatkozásában 10 év) volt. Az új szabályozás szerint azonban a maximálisan kiköthető várakozási idő 26 hét (már meglévő egészségi állapot vonatkozásában pedig 5 év). Megjegyezzük, hogy az anyasággal kapcsolatos ellátások tekintetében mind a régi, mind az új szabályozás szerint legfeljebb 52 hetes várakozási időt lehet kikötni (HIA).
Ausztráliában legfeljebb 12 hónap lehet a várakozási idő már meglévő egészségi állapot vonatkozásában, valamint az anyasággal kapcsolatos ellátások tekintetében is. Minden más ellátás vonatkozásában viszont legfeljebb két hónap. A pszichiátriai, a rehabilitációs és a palliatív kezelések annyiban sajátosak a várakozási idő tekintetében, hogy ezeknél még a szerződéskötéskor már meglévő egészségi állapot esetén is csak kéthónapos várakozási idő köthető ki (PHIO)

Végül megemlítjük, hogy a Dél-afrikai Köztársaságban az általános várakozási idő legfeljebb 3 hónap, a már meglévő egészségi állapot vonatkozásában 12 hónap, terhesség tekintetében pedig 24 hónap lehet (CMS). A fent bemutatott országokra általánosan jellemző az, hogy biztosítóváltás esetén a korábbi biztosítónál letöltött várakozási időt az új biztosítónak figyelembe kell vennie.

Ugyanakkor arra is találunk példát, hogy a jogalkotó kiterjedt önkéntes magán-egészségbiztosítási rendszer mellett egyáltalán nem szabályozza a várakozási idő maximális mértékét (lásd például Spanyolországot). Ennek több oka is lehet: egyrészt ahogyan már fent is említettük, a hosszabb várakozási idők alkalmazása nemcsak a biztosító, hanem az egész kockázatközösség érdeke is lehet. Másrészt vannak olyan speciális ellátások, amelyek egészségbiztosítási fedezete kifejezetten hosszú várakozási idő alkalmazását indokolja. Így abban az esetben, ha a jogalkotó néhány hónapos időtartamra korlátozza a várakozási időt, akkor a biztosítók jó eséllyel nem fogják ezeknek a kezeléseknek a költségét megtéríteni. Példaként a mesterséges megtermékenyítést említenénk, amelynek esetén Spanyolországban 24-48 hónapos várakozási időt is alkalmaznak a biztosítók (Polizamedica). Nagyon valószínű, hogy ha a spanyol jogalkotó is - néhány hónapban vagy egy évben - határozná meg a várakozási idő maximális terjedelmét, akkor a mesterséges megtermékenyítés kimaradna a spanyol biztosítók által nyújtott biztosítási termékekből.

\section{Szerződés módosítása}

Az egészségbiztosítások annyiban sajátos biztosítások, hogy a biztosítás időtartama alatt a biztosított kockázata jellemzően növekszik. Egyrészt a biztosítottak egyre idősebbek és egyre betegebbek lesznek (nő a különös kockázat), másrészt nő a várható élettartam, fejlődik az orvosi technika, egyre drágábbak lesznek az egészségügyi beavatkozások, így az egész kockázatközösség egészségbiztosítási kockázata is nagyobb lesz (nő az általános kockázat). Ez a kétféle kockázatnövekedés azonban eltérő megközelítést igényel.

A különös kockázat növekedése jellemzően előre kalkulálható, és nem a biztosított magatartásának függvénye. Éppen ezért várható el a biztosítótól, hogy a díjat előre ennek megfelelően alakítsa ki (például a növekvő életkorra képzett tartalékot alkalmazzon), és ne emelje folyamatosan a biztosítási díjat a kockázat növekedésének megfelelően. Ugyanis ha ezt tenné, akkor idősebb korban, amikor igazán szüksége lenne az ügyfélnek az egészségbiztosításra, az már megfizethetetlenül drága lenne a számára. Ennek megfelelően számos jogrendszerben az egészségbiztosítási szerződésekre a biztosított kockázatának megnöveke- 
désére különös szabályokat kell alkalmazni. Például a német VVG 194. \$ (1) bekezdése vagy az osztrák VersVG 178a. \$ (3) bekezdése kizárja azoknak az általános biztosítási szerződési szabályoknak az alkalmazhatóságát az egészségbiztosítási szerződések körében, amelyek a biztosító számára más biztosítások esetén lehetővé teszik a díj emelését (a szerződés módosítását) a biztosított kockázatának megnövekedése esetén. Vagy a holland Ptk. 7:940. § (5) bekezdése szerint a biztosító nem szüntetheti meg, valamint nem módosíthatja a szerződést a biztosított egészségi kockázatainak megnövekedése miatt, ha ezek a biztosított valamely személyes tulajdonságához vagy jellemzőjéhez kapcsolódnak. A francia Code des assurances L113-4. \$-ának utolsó mondata pedig kizárja a biztosítási kockázat növekedésére vonatkozó szabályok alkalmazását élet- és egészségbiztosítás esetén, ha a biztosított egészségi állapota változik meg.

\section{Az egészségbiztosítások időtartama alatt a \\ biztosított kockázata jellemzően növekszik.}

A különös kockázattal szemben az általános kockázat változása nem mérhető fel több évtizedes időtávlatra (nem kalkulálható pontosan, hogy mennyibe fognak kerülni egyes beavatkozások a távolabbi jövőben, vagy hogyan fog növekedni a várható élettartam, stb.). Ha ezt a költségnövekedést a biztosítónak kellene viselnie, akkor az veszélyeztetné a hosszú távú fizetőképességét, amely összeegyeztethetetlen a biztosítókra vonatkozó közjogi szabályokkal. Ezért elkerülhetetlen, hogy e körülmények megváltozása miatt az egészségbiztosítás léte alatt a szerződést a változásokhoz (növekvő költségekhez) igazítsák. Ertelemszerüen a módosítást mindig a biztosító fogja kezdeményezni, de mivel az az ügyfél számára hátrányos következményekkel, elsősorban a díj emelkedésével jár, abba az ügyfél önként nem egyezne bele. Ebből kifolyólag számos országban a jogalkotó szabályozza ezt a folyamatot. E szabályozásoknak az a céljuk, hogy a biztosító kezdeményezésére módosulhasson a szerződés, de csak azokban az esetekben, ha az valóban megalapozott.

Belgiumban például a biztosító az egészségbiztosításnak a biztosítási díját, az önrészét és az általa fedezett ellátást a biztosítási évfordulókor kizárólag a fogyasztói árindex, az „egészségügyi” index (amennyiben mértéke meghaladja a fogyasztói árindexét) vagy az érintett biztosítótársaság kérelmére eljáró, a biztosítótársaságok felügyeletét ellátó közigazgatási hatóság engedélye alapján módosíthatja, az utóbbi esetben is csak akkor, ha a hatóság megállapítja, hogy a díj alkalmazása - e kétfajta index alapján számított kiigazítások ellenére - a vállalkozás számára veszteséghez vezet vagy vezethet. Megjegyezzük, hogy az Európai Unió Bírósága vizsgálta ezt a szabályozást, és C-577/11. számú, 2013. március 7-én kelt ítéletében megállapította, hogy az nem ellentétes az uniós joggal.

A német VVG 203. $\$(2)-(3)$ és (5) bekezdései szintén részletesen szabályozzák ezt a folyamatot. E rendelkezések alapján helyettesítő egészségbiztosítások körében a biztosító egyrészt jogosult a biztosítási díjaknak a módosítására, ha a díj meghatározásának alapjául szolgáló tényezők körében (ezek csak a biztosító szolgáltatásai és a halálozási statisztikák lehetnek) elöreláthatólag tartós változás áll be. Másrészt az általános biztosítási feltételeket és a díjszabási rendelkezéseket akkor módosíthatja, ha az egészségügyi viszonyok megváltoznak, és az az ügyfelek érdekeinek megóvása végett indokolt. Mindkét esetben további feltétel, hogy a biztosító módosítási javaslatát egy független szakértőnek át kell vizsgálnia, és ahhoz hozzá kell járulnia.

Az osztrák VersVG 178f., 178g., 178h. és 178m. paragrafusai is meglehetősen alaposan rendezik ezt a kérdést. Így meghatározzák azt, hogy milyen esetben és hogyan módosíthatja egyoldalúan a biztosító a szerződést. A szerződés módosítására csak meghatározott okból (például meghatározott index használata, átlagos várható élettartam változása, a szolgáltatások igénybevétele gyakoriságának vagy a szolgáltatási díjaknak a változása) kerülhet sor. Ezzel kapcsolatban a jogszabály kifejezetten kimondja, hogy az életkor növekedése vagy az egészségi állapot romlása nem adhat okot szerződésmódosításra. Ha a szerződő fél nem vállalja a megnövelt díjat, akkor arányosan módosított szolgáltatást kell felajánlani neki. A tervezett módosításról egyébként a jogszabályban meghatározott hatóságokat és szervezeteket értesíteni kell, amelyek az általuk érvénytelennek tartott szerződésmódosítás mellőzése érdekében közérdekű keresetet nyújthatnak be az értesítést követő három hónapon belül. E hatóságok és szervezetek jogosultak a biztosítók vonatkozó kockázatszámítási adatbázisaiba betekinteni. A biztosító nemcsak a díjat, hanem a biztosítási védelmet is megváltoztathatja.

Ausztráliában a biztosítók két okból emelhetik meg a biztosítások díját: egyrészt ha valamely kórházi, gyógyszer- vagy más egészségügyi költség növekszik, másrészt, ha a biztosítottak által igénybe vett szolgáltatások száma (vagy az igénybevétel gyakorisága) növekszik. A biztosítónak indokolt javaslatot kell készítenie a díjemelésről, amelyet egy szakmai bizottság véleményez, és ennek alapján az egészségügy-miniszter hagyja jóvá. Miniszteri jóváhagyás hiányában a díjemelés nem hatályosul (PHIO). Ehhez hasonlóan Szlovéniában is jóvá kell hagynia a díjemelést nemcsak a biztosító aktuáriusának, hanem a biztosításfelügyeleti hatóságnak is (Thomson-Mossialos, 2009).

Végül megjegyezzük, hogy a kiegészítő biztosításokat szigorúan szabályozó Írországban éppen a dijmódosítást nem szabályozzák, nem felügyelik (HIA).

\section{A szerződés megszűnése}

Az egészségbiztosítás megszűnésére vonatkozó szabályok rendkívül fontosak. Ennek az az oka, hogy az ügyfelet rendkívül hátrányosan érintheti az, ha megszünik az egészségbiztosítása, hiszen az idő elteltével az egészségbiztosítási kockázatának folyamatos növekedése (nő az életkora, egyre betegebb lesz, stb.) miatt egyre kedvezőtlenebb feltételekkel tud másik egészségbiztosítást kötni.

A biztosítóknak viszont az az érdekük, hogy a kockázatosabb biztosítottak (tehát a betegek és az idősek) kikerüljenek a kockázatközösségből. Éppen ezért több országban is (például Spanyolország vagy az Egyesült Királyság) elterjedt az a gyakorlat, hogy egy évre szóló, határozott időtartamú szerződéseket kötnek, amelyeket bizonyos életkor után (körülbelül a 65. 
életév) nem újítanak meg (Thomson-Mossialos, 2009). Tehát akkor veszítik el az ügyfelek az egészségbiztosítási védelmüket, amikor a leginkább szükségük lenne rá.

Ez ellen megoldást az élethosszig tartó fedezet (lifetime cover) jogszabályi előírása jelent. Értelemszerűen vonatkozik ez a szabályozás a kötelező egészségbiztosításokra (például Hollandia, Svájc vagy Németországban a helyettesítő biztosítások), de több olyan országot is találhatunk, amelyekben a kiegészítő biztosításokra is alkalmazzák: például Ausztrália (PHIO), Írország (HIA), Ausztria, Szlovénia (az állami egészségügy igénybevétele során a betegek által megtérítendő költségeket fedező egészségbiztosítások tekintetében) és Bel gium (Thomson-Mossialos, 2009). Az élethosszig tartó fedezetet jellemzően úgy írják elö, hogy kötelezik a biztosítókat arra, hogy határozatlan idejű szerződéseket kössenek (például Ausztriában, ahol a VersVG 178i. \$ (1) bekezdése alapján főszabály szerint az egészségbiztosítási szerződések csak határozatlan ideig tarthatnak, de kivételesen lehet - például rövid ott-tartózkodás esetén - egy évnél rövidebb időtartamra is egészségbiztosítást kötni), vagy a határozott idejü (általában egy évre kötött) szerződéseket azonos feltételekkel újítsák meg például Írországban (HIA). Az élethosszig tartó fedezet megteremtésének másik pillére a biztosító felmondási jogának korlátozása. Ennek az a lényege, hogy a biztosító ne szüntethesse meg azoknak a biztosítottaknak a biztosítási védelmét, akiknek az egészségbiztosítási kockázata jelentősen megnövekszik. Így a jogalkotó meghatározza azokat az eseteket, amikor a biztosító felmondhatja az egészségbiztosítási jogviszonyt. Ennek megfelelően a biztosítók élethosszig tartó fedezet esetén nem jogosultak az egészségbiztosítási szerződés rendes felmondással való megszüntetésére. Ez jellemzően csoportos biztosításokra nem vonatkozik, de az ezek által nyújtott fedezet megszűnésekor a biztosítottak arra válnak jogosulttá, hogy egyéni biztosításként folytassák a korábbi egészségbiztosítási jogviszonyt (lásd például a belga vagy az osztrák szabályozást). Azt is gyakran meghatározzák, hogy a biztosító milyen esetben élhet a rendkívüli felmondás jogával (lásd például Szlovéniát, Belgiumot, Ausztriát vagy a Dél-afrikai Köztársaságot). Ez a dífizetési kötelezettség elmaradása, a közlési kötelezettsége megsértése vagy a biztosított egyéb megtévesztő magatartása lehet. Megjegyezzük, hogy Ausztriában a VersVG 178k. \$-a alapján a közlési kötelezettség megsértése miatt a biztosító a felmondási jogát csak a szerződés megkötését követő első három évben gyakorolhatja.

\section{Az élethosszig tartó fedezet megteremtésének másik}

pillére a biztosító felmondási jogának korlátozása.

\section{Konklúzió}

A fentiek alapján azt vehetjük észre, hogy azokban az országokban, amelyekben a jogalkotó legalább egyes egészségbiztosítások vonatkozásában a részletesebb szabályozás mellett döntött, a megoldások koncepciója azonos célok és elvek mentén halad: minél több ember számára elérhető árú hozzáférést biztosítani magas színvonalú szolgáltatásokat és széles biztosítási fedezetet nyújtó egészségbiztosításokhoz.
Az egyes államok szabályozása azonban az egyértelmű hasonlóságok ellenére lényeges eltéréseket is mutat. Például Írországban előíriák a kötelező befogadást, a közös díjszabást és az élethosszig tartó fedezetet, de a biztosítók szabadon módosíthatják a szerződéseket. Ugyanakkor Ausztriában erősen korlátozzák a biztosítókat abban, hogy módosítsák az egészségbiztosítási szerződéseket, valamint elöírják az élethosszig tartó fedezetet, de sem a kötelező befogadást, sem a közös díjszabást nem alkalmazzák.

Az egyes különbségeknek álláspontunk szerint két oka van. Egyrészt a szabályozási célok egymásnak ellentmondó törekvéseket jelentenek. Ugyanis ha egyre több magasabb kockázatú személy kerül bele a kockázatközösségbe, az az egész közösség kockázatát szükségszerüen növeli, ami magasabb biztosítási díjakat generál. Ebből kifolyólag nincsenek egyértelműen jól müködő szabályozási eszközök. Könnyen belátható ugyanis, hogy ha a biztosítókat arra kötelezik, hogy mindenkinek nyújtsanak biztosítást, akkor vagy a szolgáltatási csomagok tartalma csökken, vagy a díjak emelkednek meg jelentősen.

Az eltérések másik oka az egyes országok egészségügyi rendszere közötti különbségek, amelyekbe a magán-egészségbiztosításoknak és a szabályozásuknak be kell épülniük. Az eltérő funkciójú egészségbiztosítások eltérő szabályozást vonnak maguk után. Jellemzően azokban az esetekben találkozunk erősen és részletesen szabályozott magán-egészségbiztosítással, ahol az állami egészségügyi szolgáltatások igénybevétele során a lakosság vagy annak egy jelentős része köteles a költségeket legalább részben megtéríteni (például Belgiumban, Írországban és Szlovéniában).

Így megállapíthatjuk, hogy nincsen általánosan bevált, biztos recept a magán-egészségbiztosítások szabályozására. Ennek ellenére kifejezetten hasznos lehet a külföldi trendek figyelemmel kísérése, hiszen az alapvető célok és a rendelkezésre álló szabályozási eszközök az egyes országokban hasonlóak, így lehet tanulni mások sikereiből és kudarcaiból egyaránt.

\section{IRODALOMJEGYZÉK}

Bach-Moser (2009): Private Krankenversicherung - MB/KK- und MB/KT-Kommentar, München Beckmann-Matusche-Beckmann (2009): Versicherungsrechts Handbuch, Munchen

CCGF: Canadian Coalition for Genetic Fairness http://www.ccgf-cceg.ca/en/about-genetic-discriminatio

García-Armesto-Abadía-Taira-Durán-Hernández-Quevedo-Bernal-Delgado (2010): Spain: Health System Review. Health Systems in Transition http://www.euro.who.int/__data/assets/pdf_file/0004/128830/294549.pd

Gerken-Merkur (2010): Belgium: Health System Review. Health Systems in Transition

http://www.euro.who.int/_data/assets/pdf_file/0014/120425/E94245.PD

surance-in-the-netherlands/health-insurance-in-the-netherlands.pd Langheid-Wandt (2009-2010): Münchener Kommentar zum Versicherungsvertragsgesetz, München Obamacare: http://obamacarefacts.com/

PHIO: Private Health Insurance Ombudsman http://www.phio.org.at/

ns/private-medicalinsurance p

Polizamedica-htp:/www polizamedica.es/comparar-seguro-medico/periodo-de-carencia.html

- Mossialos. Private health insurance in the European Union. LSE-European Commission, 2009

http://ec.europa.eu/social/BlobServlet?docId=4216\&langId=e 